\title{
Comparison of organic and inorganic fertilizer effect when combined with biochar and alternate wetting and drying on methane emission and yield of rice cultivation
}

\author{
Patikorn Sriphirom $^{1 *}$, Amnat Chidthaisong ${ }^{1,2}$, Kazuyuki Yagi ${ }^{1}$ and \\ Sirintornthep Towprayoon ${ }^{1,2}$ \\ ${ }^{1}$ The Joint Graduate School of Energy and Environment (JGSEE) and Center of Excellence on Energy \\ Technology and Environment (CEE), King Mongkut's University of Technology Thonburi (KMUTT), \\ Bangkok 10140, Thailand \\ ${ }^{2}$ Earth System Science Research Cluster, King Mongkut's University of Technology Thonburi (KMUTT), \\ Bangkok 10140, Thailand
}

\begin{abstract}
Biochar and alternate wetting and drying (AWD) are acceptable technologies for methane $\left(\mathrm{CH}_{4}\right)$ emission mitigation and yield increase of rice growing. However, both technologies should be used together with fertilizers to enhance more yield in order to promote farmer application. This study was conducted to evaluate the effects of organic (compost) and inorganic fertilizer when combined biochar as co-application with AWD on $\mathrm{CH}_{4}$ emission, rice yield and water use in rice cultivation. Rice was transplanted in the experimental field under CF and AWD water managements in wet and dry seasons. Biochar, compost and chemical fertilizer was amended at rate of $10 \mathrm{tha}^{-1}$ year ${ }^{-1}, 1.5 \mathrm{t} \mathrm{ha}^{-1}$ season $^{-1}, 90 \mathrm{~kg} \mathrm{~N} \mathrm{ha}^{-1}$ season ${ }^{-1}$, respectively. $\mathrm{CH}_{4}$ emission was measured by using the closed chamber technique. The result showed that co-application of biochar with compost (BC) and co-application with chemical fertilizer (BF) contributed more $\mathrm{CH}_{4}$ emission from rice cultivation in both seasons as compared to biochar application alone (BI). When compare only co-application found that the $\mathrm{CH}_{4}$ emission of $\mathrm{BC}$ was still lower than $\mathrm{BF}$. $\mathrm{CH}_{4}$ emission of all treatments were further reduced when managed water under AWD by an average of $10.4 \%$ in wet season and $27.6 \%$ in dry season. Both BC and BF could significantly enhance rice yield in both seasons which found a greater increase in BF. The yield increase under AWD need to successful implementation because unsuccessful AWD affected the yield reduction. Yield enhancement related to the increase of tiller and panicle number. Chemical fertilizer strongly influenced the increases of emission, rice growth and yield over compost. In term of water use it was reduced under AWD water management. Therefore, $\mathrm{BC}$ combined with successful AWD that could reduce $\mathrm{CH}_{4}$ emission as compared to $\mathrm{BF}$ and increase yield as compared to $\mathrm{BI}$ is the optimal practice for adoption promotion of farmers to $\mathrm{CH}_{4}$ mitigation with satisfaction in yield production.
\end{abstract}

Keywords: biochar co-application; alternate wetting and drying; $\mathrm{CH}_{4}$ emission; rice yield

\section{Introduction}

Rice growing is the important anthropogenic sources of methane $\left(\mathrm{CH}_{4}\right)$ emission (Conrad, 1993) that contributed 54.06 $\mathrm{Tg} \mathrm{CH}_{4}$ in 2016 from 350.07 million hectares of total rice harvested area (FAO, 2018). The acceptable technologies for $\mathrm{CH}_{4}$ emission mitigation form rice growing with yield increase is biochar (Kim et al., 2017). Many studies reported the reduction of $\mathrm{CH}_{4}$ emission from rice paddy when amended biochar into the soil (Feng et al., 2012, Xie et al., 2013). Wang et al. (2018) showed that annual total $\mathrm{CH}_{4}$ emission was reduced by $20-51 \%$ as compared to treatment without biochar. Kim et al. (2017) demonstrated that biochar with urea reduced $\mathrm{CH}_{4}$ emission by $33.8 \%$ as compared to urea alone. Biochar also was reported the enhancement of rice yield (Zhang et al., 2012) through the utilization promotion of soil nutrients for plant growth development (Sang et al., 2019). Bhattacharjya et al. (2015) reported that biochar increase nutrients uptake and nutrients use efficiency of rice growing. However, the yield effect of biochar is still uncertain due to was found the opposite 
reports that showed the decrease or no change in rice yield as compared to no amendment soil or traditional practice of farmer (Zhang et al., 2010). Xie et al. (2013) showed the reduction in grain yield by $12.2-37.5 \%$ of biochar amendment while Asai et al. (2009) showed no change of rice yield when compared with no amendment soil although applied in different rates. Partey et al. (2014) reported that biochar increased the yield by $45.5 \%$ as compared to no amendment soil but it was still lower than fertilizer application by $50.0 \%$. This reason may be the major barrier of the widespread biochar adoption of farmers. Biochar should be combined with fertilizers as co-application in order to increase the rice yield (Xie et al., 2013, Kim et al., 2017), but fertilizer was reported the increase of emission (Bédard and Knowles, 1989, Conrad and Rothfus, 1991). Therefore, AWD was introduced to combine with biochar co-application to enhance the emission reduction.

AWD has been developed and promoted by the International Rice Research Institute (IRRI) to replace traditional continuous flooding (CF) (Carrijo et al., 2017). It showed the mitigation potential of $\mathrm{CH}_{4}$ emission from rice cultivation by an average of $43.1 \%$ (Sander et al., 2015). It was adopted in many countries to mitigate the GHG emissions from agricultural sector (Jiang et al., 2019) but still few studies in Thailand. AWD also showed the potential in yield enhancement through effective tiller and panicle increase (Khairi et al., 2016). Tran et al. (2018) and Ye et al. (2013) reported the yield increase of AWD ranging from 5.10\% to $10.3 \%$. On the other hand, Blango et al. (2019) and Linquist et al. (2015) demonstrated that AWD decreased rice yield while Pandey et al. (2014) reported no change in rice yield as compared to continuous flooding. The effect on yield of AWD is still limited, although studies in many regions which causes uncertainty to those who will be used. In addition, AWD could reduce water consumption of rice cultivation that was found around $14.8-45.3 \%$ (Lampayan et al., 2015, Sibayan et al., 2018, Tran et al., 2018) as compared to continuously flooded.

Therefore, the combination of biochar co-application with fertilizers and AWD is interesting to study. The compost and chemical fertilizer were chosen to use as organic and inorganic fertilizer in this experiment, respectively. This study aims to evaluate the effects of organic and inorganic fertilizers when combined with biochar as co-application and AWD on $\mathrm{CH}_{4}$ emission, rice growth and yield and water use in rice cultivation to recommend the farmers practice that can reduce $\mathrm{CH}_{4}$ emissions without yield compromising.

\section{Materials and methods}

\section{Experimental field}

The experimental field is located at Chom Bueng District, Ratchaburi Province, Thailand (13 $35^{\prime} 10^{\prime \prime} \mathrm{N} \& 99^{\circ}$ $30^{\prime} 21^{\prime \prime}$ E) as shown in Figure 1. The average of air temperature and precipitation during the experiment period was $28.12{ }^{\circ} \mathrm{C}$ and $2.80 \mathrm{~mm}$ day -1 , respectively. The soil of this experimental site was classified as Khao Yoi (Kyo) Thai soil series with a sandy loam texture. The physical and chemical properties of $0-20 \mathrm{~cm}$ soil depth contained $6.12,0.86 \%, 0.31 \%, 0.08 \%, 52.91 \mathrm{mg} \mathrm{kg}-1,85.39 \mathrm{mg} \mathrm{kg}-1,4.94 \mathrm{cmol} \mathrm{kg}-1$, ang $1.64 \mathrm{~g} \mathrm{~cm}-3$ of $\mathrm{pH}$, organic matter $(\mathrm{OM})$, total carbon $(\mathrm{C})$, total nitrogen $(\mathrm{N})$, available phosphorus $(\mathrm{P})$, available potassium $(\mathrm{K})$, CEC, and bulk density (BD), respectively. 


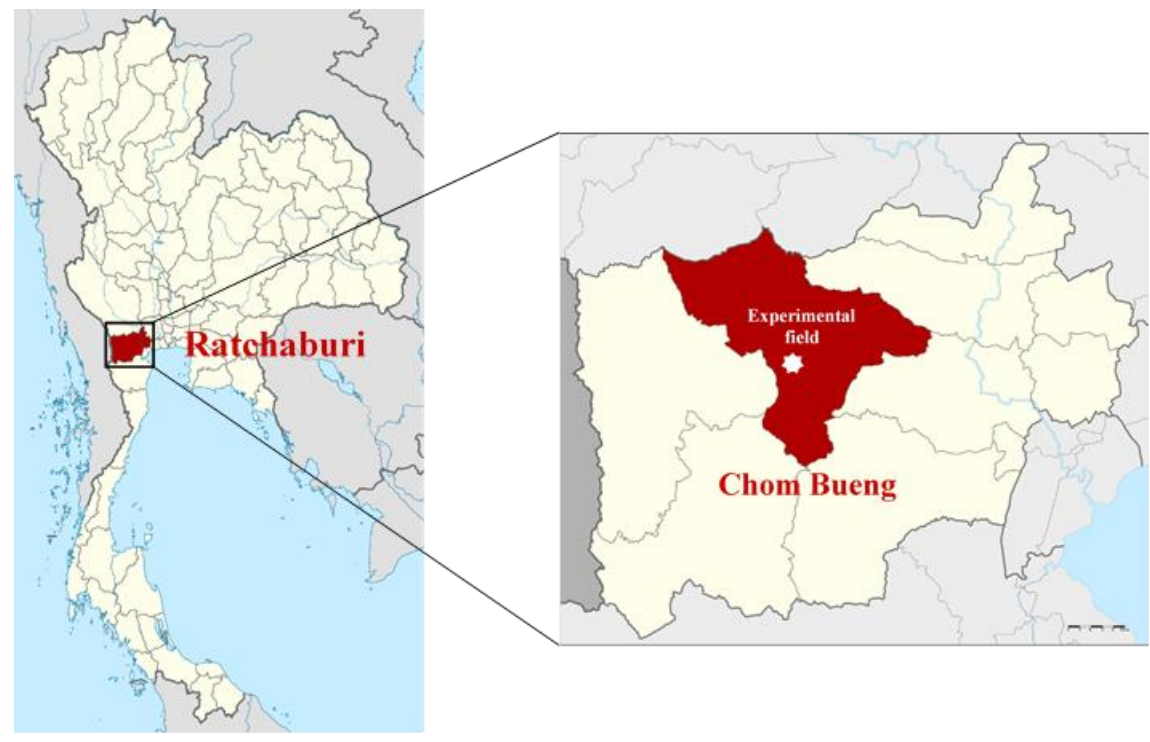

Figure 1 Map showing the location of the experimental field in Ratchaburi Province, Thailand.

\section{Soil amendment materials}

Mangrove (Rhizophora apiculata) biochar at size of 1-2 mm, Bangkok compost, and inorganic fertilizer were amended at rate of $10 \mathrm{t}$ ha-1year-1 (assume that two season per year), $1.5 \mathrm{t} \mathrm{ha}-1$ season-1, and $90 \mathrm{~kg} \mathrm{~N}$ ha-1season-1, respectively. The properties of biochar contained 7.94, $1.27 \mathrm{dS} \mathrm{m}-1,11.19 \%, 65.94 \%, 0.24 \%$, $0.23 \%, 0.10 \%$, and $13.87 \mathrm{cmol} \mathrm{kg-1}$ of $\mathrm{pH}$, electrical conductivity (EC), OM, C, N, P, K, and CEC, respectively. Bangkok compost was 100\% genuine organic fertilizer that contained 7.12, 51.45\%, 19.10\%, and $0.85 \%$ of $\mathrm{pH}, \mathrm{OM}, \mathrm{C}$, and $\mathrm{N}$, respectively.

\section{Field experimental design and crop cultivation management}

The Pathumthani 1 rice (Oryza sativa L.) cultivar were planted to be the seedlings in the tray for 2 weeks and moved to transplanting (initial 4 tillers per hill) in the experimental field under continuous flooding (CF) and AWD water managements. Biochar and compost were incorporated into the soil at approximate depth of 20-30 $\mathrm{cm}$ before 15 days of transplanting by a tractor (Kubota L4708SP, Siamkubota, Thailand). Chemical fertilizer was applied during cultivation season for two times, compound fertilizer (15-15-15) was added at 20 days after transplanting (DAT) as basal fertilizer at rate of $33 \mathrm{~kg} \mathrm{~N}$ ha-1 while urea (46-0-0) was added at 60 DAT as top dressing at rate of $57 \mathrm{~kg} \mathrm{~N}$ ha-1. This study consist of treatments of this study were biochar application (BI), biochar co-application with compost (BC), and biochar co-application with chemical fertilizer (BF) under CF and AWD water managements, total is 6 treatments. Rice was cultivated for two seasons were wet season (WS) during August to December and dry season (DS) during February to June. The crops duration (transplanting to harvesting) of control, co-application with compost and co-application with chemical fertilizer were 116, 115, and 110 days in wet season and 118, 116, and 111 days in dry season, respectively. This experiment was carried out in a randomized complete block design which each plot size was $20 \mathrm{~m} 2$.

\section{Water management}

Water level was continuously flooded at $5 \mathrm{~cm}$ above the soil surface since transplanting until complete grain formation stage (around 2-3 weeks before harvesting) for CF (Figure 2 (a)). While AWD, water level was controlled at $5 \mathrm{~cm}$ above the soil surface since transplanting to 20 DAT. After 20 DAT that was in tillering stage, the field was naturally dried through percolation, evapotranspiration and seepage until the water level reached $15 \mathrm{~cm}$ below the soil surface according to the safe AWD guideline of IRRI (Li, 2001, Adhya et al., 2014). After that, the field was re-flooded at $5 \mathrm{~cm}$ above soil surface and allowed to naturally be dried again for 
the next cycle of AWD until the commencement of booting. Water level of AWD was naturally dried again after complete grain formation stage for harvesting preparation (Figure 2 (b)). Both water managements were continuously flooded since booting to grain formation stages in order to yield reduction prevention (Bouman et al., 2007).
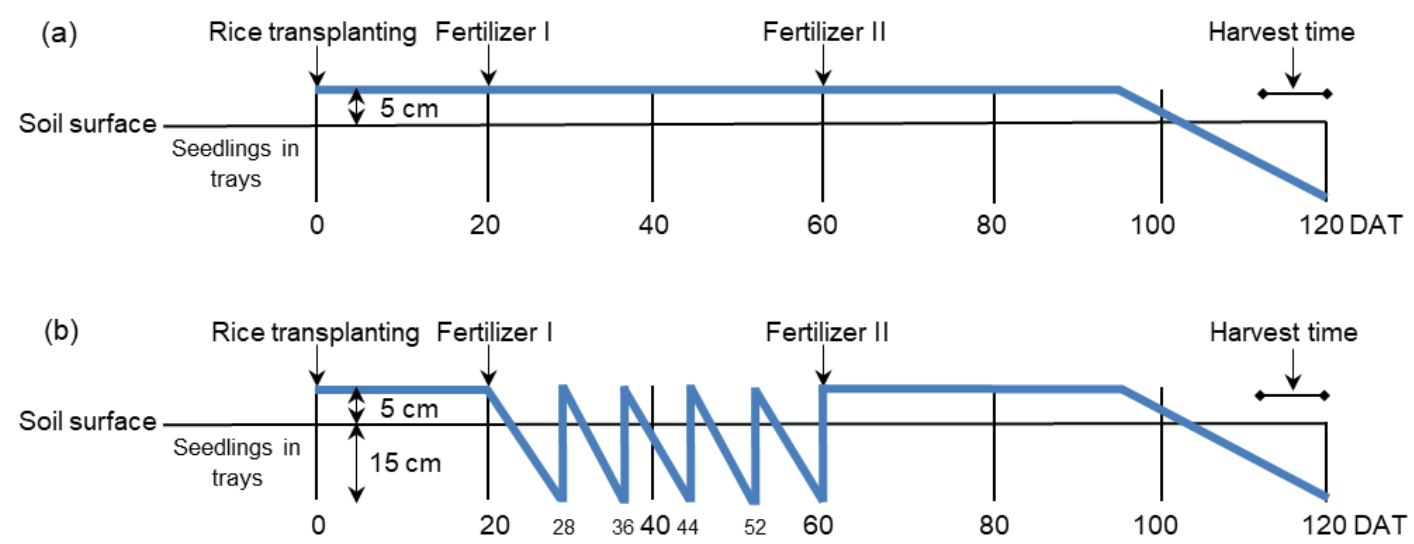

Figure 2 Schematic diagrams of water management under $C F(a)$ and AWD (b).

Water management followed AWD in this study was unsuccessful in the wet season because of the rainfall interference but was successfully implemented in the dry season. The successful AWD was defined here as the field conditions that could successively dry at $15 \mathrm{~cm}$ below the soil surface throughout the tillering stage. Whereas, the unsuccessful AWD was defined as the field conditions that water level could not be reached $15 \mathrm{~cm}$ below the soil surface due to water level increase in the field as a result of rainfall during the tillering stage and the dry cycle of AWD could not be continued successively. In this experiment, AWD could dry only one cycle for all treatments in the wet season, while could dry for 5 cycles in BFC and BFA treatments and 6 cycles in BIC, BIA, BCC and BCA treatments in the dry season. Water level in the fields was manually monitored with a measure stick on a PVC tube (Nasir et al., 2014).

\section{$\mathrm{CH}_{4}$ emission measurement}

The $\mathrm{CH}_{4}$ emission was measured using the closed chamber method (Minamikawa et al., 2015) throughout cultivation season. The acrylic opaque chamber was used for gas sampling with 3 points per each plot. The air in chamber's headspace was usually sampled once a week but for AWD it had additional sampling on the driest day and re-flooding day. It was conducted during 10.30 am to $12.00 \mathrm{pm}$ in different times at $0,5,10$ and 15 mins after chamber closure. The air samples were transferred from the chamber into the vacuum glass vial through plastic syringe to move to analysis.

The samples were immediately analyzed the concentration of $\mathrm{CH}_{4}$ by a gas chromatograph (GC). GC equipped with a flame ionization detector (FID) and Unibead C Packed column (Shimadzu GC-2014, Japan), using helium as a carrier gas. $\mathrm{CH}_{4}$ flux was calculated by using the equation given by Minamikawa et al. (2015) that computed from linear regression of the gas concentration increase in the chamber headspace (ppmv) over the sampling time. The seasonal cumulative $\mathrm{CH}_{4}$ emissions were calculated by successive linear interpolation and numerical integration between sampling days, assumed that $\mathrm{CH}_{4}$ emissions on days without the measurement were according to a linear trend (Chidthaisong et al., 2018).

\section{Water use measurement}

Irrigated water and rainwater were used for rice cultivation in this study. The water was irrigated by a water pump (VENZ VC-200, Venz Electric, Thailand) into the experimental fields to keep the water level of both water managements. Total amount of irrigated water use throughout the cultivation seasons of each plot was measured using a single jet water meter (SV 15, Sanwa, Thailand). Daily precipitation was measured at the eddy flux tower of a dry dipterocarp forest within the KMUTT Ratchaburi campus (100 $\mathrm{m}$ far from the experimental 
field) by using a Tipping Bucket Rain Gauge (TE 525 Rainfall Sensor, Campbell Scientific, USA). The total water use in rice cultivation of each treatment calculated from the summation of total irrigated water and rainwater. Rainwater that used in the calculation was the rainfall amount that increased the water level above the soil surface in the experimental field was not exceeds $5 \mathrm{~cm}$ (highest level of water level controlling).

\section{Rice growth and grain yield measurement}

The number of tiller and panicle were manually counted and the plant height was measured by measuring tape at the same time of gas sampling with 6 points per each plot. The grain yield and aboveground biomass were collected in the area of $1 \mathrm{~m}^{2}$ with 3 points per each plot on the harvesting date.

\section{Statistical analysis}

Data were showed as mean \pm SE which was determined the statistical significance at a confidence level of $95 \%$ $(P<0.05)$ by using One-way analysis of variance (ANOVA) and Duncan's multiple range test of SPSS version 22.

\section{Results and discussion}

Effect of biochar co-applications combined AWD on $\mathrm{CH}_{4}$ emission

The co-application of biochar with compost (BC) and co-application with chemical fertilizer (BF) increased the emission of $\mathrm{CH}_{4}$ in almost stages of rice cultivation as compared to biochar application alone (BI) as seen in Figure 3. As relative to $\mathrm{BI}, \mathrm{BC}$ and $\mathrm{BF}$ increased the cumulative $\mathrm{CH}_{4}$ emission by $11.4 \%$ and $45.3 \%$ in wet season and by $22.0 \%$ and $48.7 \%$ in dry season, respectively (Table 1). When compared in the case of coapplication, $\mathrm{BF}$ contributed higher $\mathrm{CH}_{4}$ emission than $\mathrm{BC}$ by $22.5 \%$ in wet season and $16.4 \%$ in dry season (Table 1). The result in Table 1 also showed the increase of $\mathrm{CH}_{4}$ emission for yield production of 1 ton in $\mathrm{BC}$ and $\mathrm{BF}$ over $\mathrm{BI}$, although this effect did not show the statistically different. When all treatments were managed the water under AWD, there could further reduce $\mathrm{CH}_{4}$ emission by an average of $10.4 \%$ in wet season and $27.6 \%$ in dry season as compared to CF. The lower reduction in wet season as result of the unsuccessful AWD implementation that could not inhibit the $\mathrm{CH}_{4}$ production with aerobic environment. 


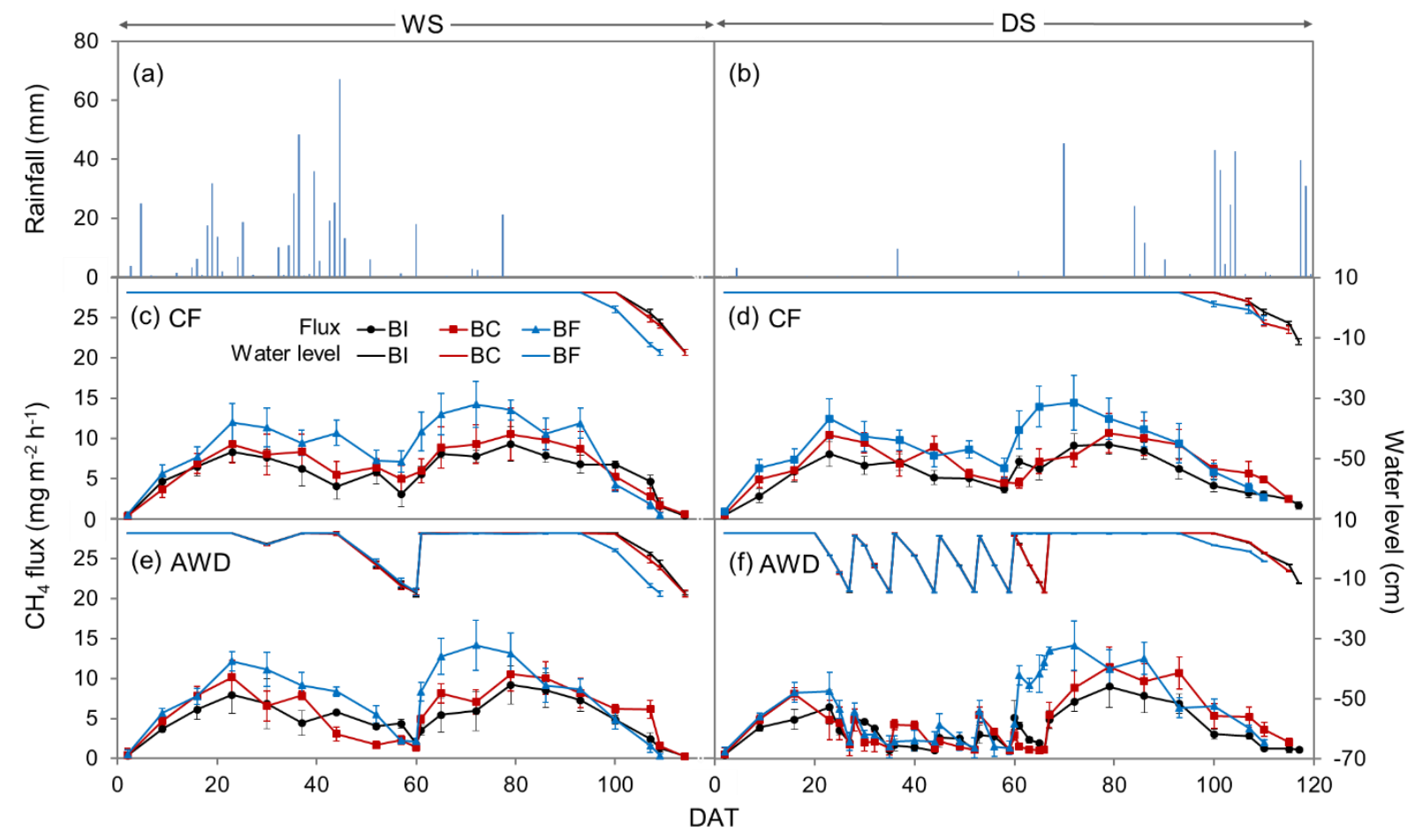

Figure $3 \quad$ Rainfall in wet (a) and dry (b) seasons with CH4 fluxes throughout rice cultivation under CF in wet season (c) and dry season (d) and under AWD in wet season (e) and dry season (f). WS: wet season; DS: dry season.

The result showed that both organic and inorganic fertilizers promoted higher emission which inorganic fertilizer strongly influenced over organic fertilizer. The increase of $\mathrm{CH}_{4}$ emission in inorganic fertilizer was supported by the study of Lindau (1994). It was due to inorganic fertilizer suppresses $\mathrm{CH}_{4}$ oxidation of methanotrophs bacteria because of ammonia and nitrate existing (Bédard and Knowles, 1989, Conrad and Rothfus, 1991) as result to strongly increased $\mathrm{CH}_{4}$ emission. Organic compound in organic fertilizer (compost) increase soil carbon availability for the methanogenesis (Mariko et al., 1991, Parashar et al., 1991). Plant growth increase (see Figure 4) in both fertilizer treatments might increase the internal air spaces and number of the plants (aerenchyma) through rice height and tiller increase for $\mathrm{CH}_{4}$ transportation from the soil water to the atmosphere (Hanson and Hanson, 1996). It was consistent with the report of Mariko et al. (1991) which indicated that rice plant was the main factor of $\mathrm{CH}_{4}$ emission and higher transportation capacity was found in larger plant stem.

Table 1 Cumulative $\mathrm{CH}_{4}$ emission, total water use, grain yield, yield-scaled $\mathrm{CH}_{4}$ emission and yield-scaled water of rice cultivation in wet and dry seasons.

\begin{tabular}{llllll}
\hline Treatment & $\begin{array}{l}\text { CH4 emission } \\
\text { (kg ha-1) }\end{array}$ & $\begin{array}{l}\text { Total water use } \\
(\mathrm{m} 3 \text { ha-1 })\end{array}$ & $\begin{array}{l}\text { Grain yield } \\
(\mathrm{t} \text { ha-1 })\end{array}$ & $\begin{array}{l}\text { Yield-scaled } \\
\text { CH4 } \\
(\mathrm{kg} \mathrm{CH} 4 \mathrm{t}-1)\end{array}$ & $\begin{array}{l}\text { Yield-scaled } \\
\text { water } \\
(\mathrm{m} 3 \mathrm{t}-1)\end{array}$ \\
\hline Wet season $(\mathrm{WS})$ & & & & \\
\hline BI-CF & $164 \pm 35.0 \mathrm{ab}$ & $11,700 \pm 364 \mathrm{a}$ & $5.14 \pm 0.15 \mathrm{~d}$ & $31.8 \pm 6.85 \mathrm{a}$ & $2,280 \pm 66.6 \mathrm{a}$ \\
\hline BI-AWD & $144 \pm 47.4 \mathrm{~b}$ & $10,500 \pm 218 \mathrm{bc}$ & $5.03 \pm 0.42 \mathrm{~d}$ & $28.5 \pm 8.59 \mathrm{a}$ & $2,080 \pm 78.4 \mathrm{~b}$ \\
\hline BC-CF & $182 \pm 50.2 \mathrm{ab}$ & $11,600 \pm 449 \mathrm{a}$ & $5.77 \pm 0.32 \mathrm{c}$ & $31.6 \pm 8.62 \mathrm{a}$ & $2,020 \pm 70.4 \mathrm{bc}$ \\
\hline BC-AWD & $166 \pm 36.9 \mathrm{ab}$ & $10,500 \pm 520 \mathrm{bc}$ & $5.56 \pm 0.28 \mathrm{c}$ & $30.1 \pm 7.54 \mathrm{a}$ & $1,880 \pm 109 \mathrm{c}$ \\
\hline BF-CF & $238 \pm 37.9 \mathrm{a}$ & $11,100 \pm 128 \mathrm{ab}$ & $6.87 \pm 0.41 \mathrm{a}$ & $34.6 \pm 5.15 \mathrm{a}$ & $1,620 \pm 41.5 \mathrm{~d}$ \\
\hline BF-AWD & $212 \pm 30.1 \mathrm{ab}$ & $10,100 \pm 187 \mathrm{c}$ & $6.28 \pm 0.15 \mathrm{~b}$ & $33.8 \pm 5.57 \mathrm{a}$ & $1,610 \pm 37.6 \mathrm{~d}$ \\
\hline Dry season $(\mathrm{DS})$ & & & & \\
\hline
\end{tabular}




\begin{tabular}{llllll}
\hline BI-CF & $159 \pm 21.6 \mathrm{BC}$ & $13,700 \pm 1,240 \mathrm{~A}$ & $5.23 \pm 0.04 \mathrm{C}$ & $30.4 \pm 4.10 \mathrm{AB}$ & $2,610 \pm 240 \mathrm{~A}$ \\
\hline BI-AWD & $113 \pm 24.4 \mathrm{C}$ & $12,900 \pm 764 \mathrm{~A}$ & $5.34 \pm 0.10 \mathrm{C}$ & $21.2 \pm 4.83 \mathrm{~B}$ & $2,430 \pm 108 \mathrm{AB}$ \\
\hline $\mathrm{BC}-\mathrm{CF}$ & $194 \pm 36.7 \mathrm{AB}$ & $13,500 \pm 953 \mathrm{~A}$ & $5.86 \pm 0.17 \mathrm{~B}$ & $33.2 \pm 6.53 \mathrm{~A}$ & $2,300 \pm 153 \mathrm{AB}$ \\
\hline BC-AWD & $145 \pm 27.7 \mathrm{BC}$ & $12,900 \pm 926 \mathrm{~A}$ & $5.92 \pm 0.10 \mathrm{~B}$ & $24.5 \pm 4.61 \mathrm{AB}$ & $2,180 \pm 188 \mathrm{BC}$ \\
\hline BF-CF & $237 \pm 40.1 \mathrm{~A}$ & $12,900 \pm 523 \mathrm{~A}$ & $6.84 \pm 0.15 \mathrm{~A}$ & $34.7 \pm 6.52 \mathrm{~A}$ & $1,880 \pm 71.3 \mathrm{C}$ \\
\hline BF-AWD & $169 \pm 41.6 \mathrm{BC}$ & $12,400 \pm 395 \mathrm{~A}$ & $6.90 \pm 0.06 \mathrm{~A}$ & $24.5 \pm 6.02 \mathrm{AB}$ & $1,800 \pm 58.5 \mathrm{C}$ \\
\hline
\end{tabular}

Different lower-case letters and capital letters indicate the significant difference in wet and dry seasons respectively.

The dried field allowing in tillering stage of AWD is the major factor of $\mathrm{CH}_{4}$ emission reduction. It changed the soil from anaerobic to aerobic environment which inhibit the $\mathrm{CH}_{4}$ production of methanogens (Zhang et al., 2009, Linquist et al., 2015). The heavy rainfall in wet season resulted to AWD could not conduct the dry field and still be anaerobic condition, resulting in it contributed higher emission than dry season. These findings consistent with the studies of Sanchis et al. (2012) and Linquist et al. (2015). The effective reduction of $\mathrm{CH}_{4}$ emission under AWD should be avoided in the area or season that a huge amount of rainfall is expected to interfere the dry field allowing in the tillering stage.

\section{Effect of biochar co-applications combined AWD on rice growth and yield}

Rice cultivation with BC and BF significantly enhanced rice yield by $12.3 \%$ and $33.7 \%$ in wet season and by $12.1 \%$ and $30.8 \%$ in dry season, respectively as compared to BI. BF significantly increased rice yield over BC by $19.1 \%$ in wet season and $16.7 \%$ in dry season as shown in Table 1 . Aboveground biomass was also increased in both co-applications in both seasons as compared to BI. When observed in the co-application case found that the biomass of $\mathrm{BF}$ over $\mathrm{BC}$ by $61.9 \%$ in wet season and $47.5 \%$ in dry season. The yield increase was supported by the increase of panicle number while biomass increase as a result of plant height and tiller increase (see Figure 4). It was resulted of nutrients availability increase from both fertilizers for the plant growth development particularly nitrogen from inorganic fertilizer as result to finding more rice growth and yield in BF than BC. This effect was supported by the studies of Alcantara et al. (1996) and Steiner et al. (2008). Seetanun and De Datta (1973) reported that nitrogen fertilizer application in flowering stage promote the increase of protein content and the possibility of grain yield development led to yield increase. Although compost would increase lower yield than chemical fertilizer, but it could increase yield as compared with BI. It was due to it is a rich source of organic matter content which is the important indicator of soil fertility that would ultimately promote crop yield increase (Sarwar et al., 2008). In addition, rice yield and growth enhancement might be due to the cobenefit that obtained from biochar and fertilizer combination because biochar can increase the uptake and the use efficiency of nutrients from fertilizer (Sang et al., 2019).

The AWD implementation in this study could increase the grain yield of all treatments only in dry season. It only increased by the average of $1.25 \%$ that not significant different with CF (Table 1). It was smaller increase number as compared to other studies (Ye et al., 2013) that might be related to site specificity such as initial soil fertility and soil type. Yield under AWD was increased through the enhancement of effective tiller number as result of dried field in tillering stage (Khairi et al., 2016). Zhang et al. (2009) and Norton et al. (2017) reported the potential of AWD for promotion of more effective tillering and the acceleration of stronger root growth of rice plants. However, the result was observed that AWD in wet season or unsuccessful AWD affected yield reduction which need to have further study to explain the cause in order to prevent the yield reduction of AWD implementation in the wet season or in area with heavy rainfall. In term of plant height found that AWD affected the plant height reduction as seen in Figure 4 (d) (Norton et al., 2017) due to dried field induced the reduction of chlorophylls content in photosynthesis (Shukla et al., 2012). It resulted biomass of AWD was lower than $\mathrm{CF}$ although AWD increased rice tiller number. 

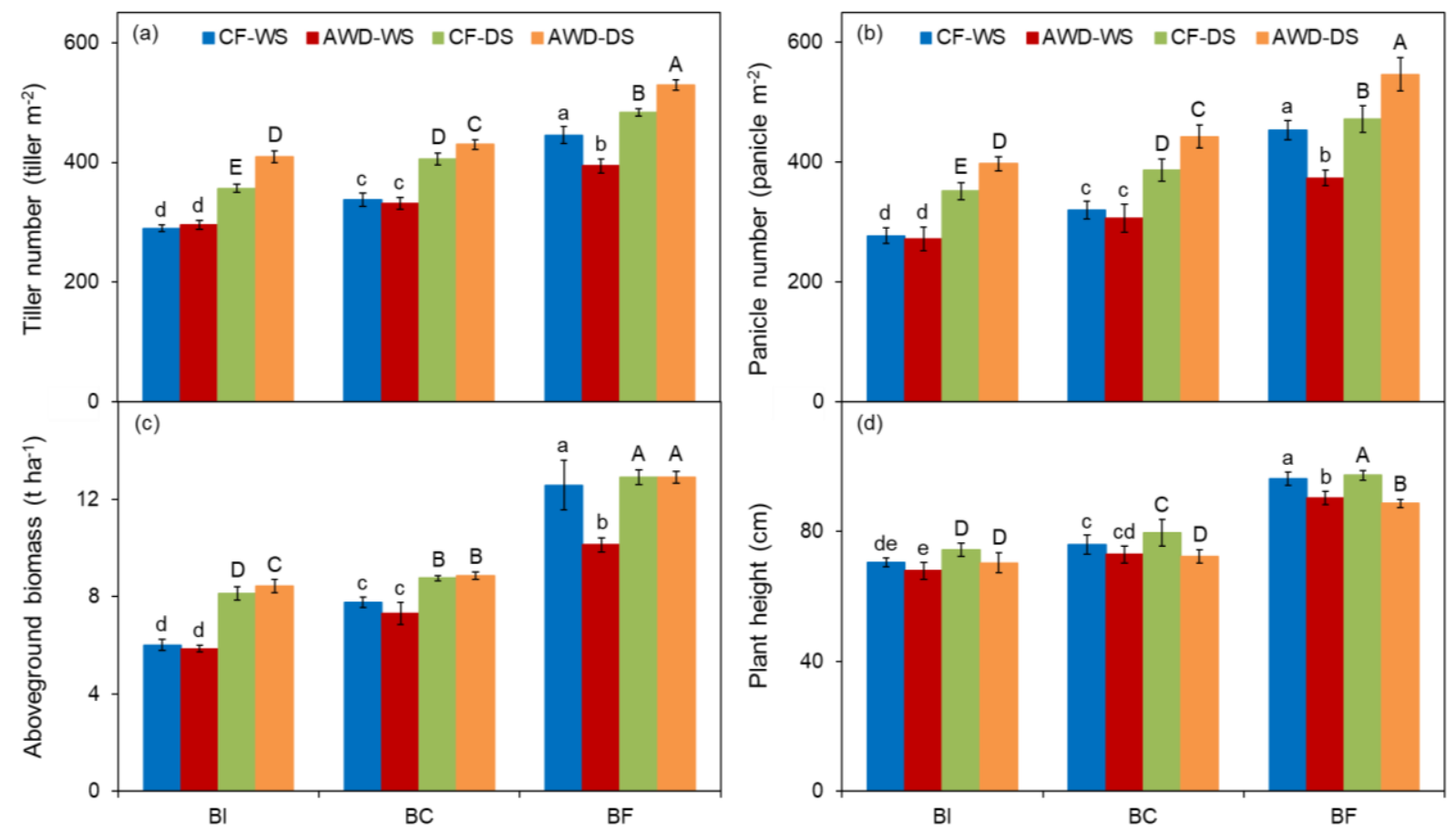

Figure $4 \quad$ Tiller number (a), panicle number (b), aboveground biomass (c), and plant height $(d)$ of rice cultivation in wet and dry seasons. Different lower-case letters and capital letters indicate the significant difference in wet and dry seasons respectively. WS: wet season; DS: dry season.

\section{Effect of biochar co-applications combined AWD on water use}

Both biochar co-applications did not show the effect on water use in rice cultivation which different amounts of water use as a result of different crop durations (Table 1). AWD affected the reduction of water use in rice cultivation particularly in wet season (Table 1). The decrease of water use in AWD as a result of the reduction of water pumping into the field in tillering stage. AWD in this study reduced total water use in rice cultivation by $10.1 \%$ in wet season and $4.55 \%$ in dry season as compared to CF. The higher reduction in wet season due to it was not conducted re-flooding the field in tillering stage because it could not allow the dried field at the level of $15 \mathrm{~cm}$ below the soil surface. Whereas, AWD in dry season could dry and need to re-flood with a new water to increase the water level up to $5 \mathrm{~cm}$ above soil surface. It was re-flooded for many times (5 - 6 times) with a huge water amount, resulting in the total water use is not much lower than CF. The water use reduction of AWD in this study is very low as compared to other studies (Chidthaisong et al., 2018, Tran et al., 2018) might be due to the soil type and evaporation rate in this study area. The further study to explain the constraints of AWD implementation in each soil type or each area zone should be conducted to recommend the farmers for adoption.

\section{Conclusions}

Biochar co-application with organic and inorganic fertilizers could enhance the rice growth and yield through the increase of tiller and panicle number and plant height. However, there are contributed higher $\mathrm{CH}_{4}$ emission than biochar application alone. It was observed that co-application with inorganic fertilizer affected higher rice yield and emission than co-application with organic fertilizer. Rice cultivation with all treatments under AWD water management was further reduced $\mathrm{CH}_{4}$ emission by average of $19.1 \%$, slightly increased yield and decreased water use as compare to CF. The practice of biochar combined with organic fertilizer under successful AWD could mitigate $\mathrm{CH}_{4}$ emission as compared to chemical fertilizer and increase rice yield as compared to biochar alone and some water saving as compared to CF. Therefore, this practice should be widespread promoted for farmer's application. 


\section{Acknowledgements}

This study was funded by the Joint Graduate School of Energy and Environment and Center of Excellence of Energy Technology and Environment at King Mongkut's University of Technology Thonburi and the Thailand Research Fund (TRF) through the International Research Network Program (IRN) (IRN57W0001, IRN5701PHDW06). The study area was provided by Earth Systems Science (ESS), King Mongkut's University of Technology Thonburi.

\section{References}

Adhya, T. K., Linquist, B., Searchinger, T., Wassmann, R., Yan, X., 2014, Wetting and drying: Reducing greenhouse gas emissions and saving water from rice production (Washington, D.C.: World Resources Institute).

Alcantara, J. M., Cassman, K. G., Consuelo, M. P., Bienvenido, O. J., Samuel, P. L., 1996, Effects of late nitrogen fertilizer application on head rice yield, protein content, and grain quality of rice. Cereal Chem, 73(5), 556-560.

Asai, H., Samson, B. K., Stephan, H. M., Songyikhangsuthor, K., Homma, K., Kiyono, Y., Inoue, Y., Shiraiwa, T., Horie, T., 2009, Biochar amendment techniques for upland rice production in Northern Laos. 1. Soil physical properties, leaf SPAD, and grain yield. Field Crops Research, 111(1-2), 81-84.

Bédard, C., Knowles, R., 1989, Physiology, biochemistry, and specific inhibitors of $\mathrm{CH}_{4}, \mathrm{NH}_{4}{ }^{+}$, and $\mathrm{CO}$ oxidation by methanotrophs and nitrifiers. Microbiology and Molecular Biology Reviews, 53(1), 68-84.

Bhattacharjya, S., Chandra, R., Pareek, N., Raverkar, K. P., 2015, Biochar and crop residue application to soil: effect on soil biochemical properties, nutrient availability and yield of rice (Oryza sativa L.) and wheat (Triticum aestivum L.). Archives of Agronomy and Soil Science, 62(8), 1095-1108.

Blango, M. M., Cooke, R. A., Moiwo, J. P., 2019, Effect of soil and water management practices on crop productivity in tropical inland valley swamps. Agricultural Water Management, 222, 82-91.

Bouman, B. A. M., Humphreys, E., Tuong, T.P., Barker, R., 2007, Rice and water. Advances in agronomy, 92, 187-237.

Carrijo, D. R., Lundy, M. E., Linquist, B. A., 2017, Rice yields and water use under alternate wetting and drying irrigation: a meta-analysis. Field Crops Research, 203, 173-180.

Chidthaisong, A., Cha-un, N., Rossopa, B., Buddaboon, C., Kunuthai, C., Sriphirom, P., Towprayoon, S., Tokida, T., Padre, A. T., Minamikawa, K., 2018, Evaluating the effects of alternate wetting and drying (AWD) on methane and nitrous oxide emissions from a paddy field in Thailand. Soil science and plant nutrition, 64(1), 31-38.

Conrad, R., 1993, Mechanisms controlling methane emission from wetland rice fields. In: Biogeochemistry of Global Change, edited by R. S. Oremland. 1993 edition (Boston: Springer, MA), pp. 317-335.

Conrad, R., Rothfuss, F., 1991, Methane oxidation in the soil surface layer of a flooded rice field and the effect of ammonium. Biology and Fertility of Soils, 12(1), 28-32.

Feng, Y., Xu, Y., Yu, Y., Xie, Z., Lin, X., 2012, Mechanisms of biochar decreasing methane emission from Chinese paddy soils. Soil Biology and Biochemistry, 46, 80-88.

Food and Agriculture Organization of the United Nations (FAO), 2018, FAOSTAT database-Rice cultivation, Date of access: 30/10/2018. http://www.fao.org/faostat/en/\#data/GR.

Hanson, R. S., Hanson, T. E., 1996, Methanotrophic bacteria. Microbiological Reviews, 60(2), 439-471.

Jiang, Y., Carrijo, D., Huang, S., Chen, J., Balaine, N., Zhang, W., van Groenigen, K. J., Linquist, B., 2019, Water management to mitigate the global warming potential of rice systems: A global meta-analysis. Field Crops Research, 234, 47-54.

Khairi, M., Nozulaidi, M., Jahan, M. S., 2016, Effects of flooding and alternate wetting and drying on the yield performance of upland rice. Pertanika Journal of Tropical Agricultural Science, 39(3), 299-309.

Kim, J., Yoo, G., Kim, D., Ding, W., Kang, H., 2017, Combined application of biochar and slow-release fertilizer reduces methane emission but enhances rice yield by different mechanisms. Applied Soil Ecology, 117 , 57-62. 
Lampayan, R. M., Samoy-Pascual, K. C., Sibayan, E. B., Ella, V. B., Jayag, O. P., Cabangon, R. J., Bouman, B. A. M., 2015, Effects of alternate wetting and drying (AWD) threshold level and plant seedling age on crop performance, water input, and water productivity of transplanted rice in Central Luzon, Philippines. Paddy and Water Environment, 13(3), 215-227.

Li, Y. H., 2001, Research and practice of water-saving irrigation for rice in China. Proceedings of the international workshop on water saving irrigation for rice, Wuhan, China, March, pp. 1-9.

Lindau, C. W., 1994, Methane emissions from Louisiana rice fields amended with nitrogen fertilizers. Soil Biology and Biochemistry, 26(3), 353-359.

Linquist, B. A., Anders, M. M., Adviento-Borbe, M. A. A., Chaney, R. L., Nalley, L. L., Da Rosa, E. F., Van Kessel, C., 2015, Reducing greenhouse gas emissions, water use, and grain arsenic levels in rice systems. Global change biology, 21(1), 407-417.

Mariko, S., Harazono, Y., Owa, N., Nouchi, I., 1991, Methane in flooded soil water and the emission through rice plants to the atmosphere. Environmental and experimental botany, 31(3), 343-350.

Minamikawa, K., Tokida, T., Sudo, S., Padre, A., Yagi, K., 2015, Guidelines for measuring $\mathrm{CH}_{4}$ and $\mathrm{N}_{2} \mathrm{O}$ emissions from rice paddies by a manually operated closed chamber method. (Tsukuba, Japan: National Institute for Agro-Environmental Sciences).

Nasir, A., Shahriar, S., Rupa, W. S., Mehraj, H., Uddin, A. F. M. J., 2014, Alternate wetting and drying irrigation system on growth and yield of hybrid Boro rice. Journal of Soil and Nature, 7(2), 28-35.

Norton, G. J., Shafaei, M., Travis, A. J., Deacon, C. M., Danku, J., Pond, D., Cochrane, N., Lockhart, K., Salt, D., Zhang, H., Dodd, I. C., Hossain, M., Islam, M. R., Price, A. H., 2017, Impact of alternate wetting and drying on rice physiology, grain production, and grain quality. Field Crops Research, 205, 1-13.

Pandey, A., Vu, D. Q., Bui, T. P. L., Mai, T. L. A., Jensen, L. S., de Neergaard, A., 2014, Organic matter and water management strategies to reduce methane and nitrous oxide emissions from rice paddies in Vietnam. Agriculture, ecosystems \& environment, 196, 137-146.

Parashar, D. C., Rai, J., Prabhat, K. G., Singh, N., 1991, Parameters affecting methane emission from paddy fields. Indian journal of radio \& space physics, 20,12-17.

Partey, S. T., Preziosi, R. F., Robson, G. D., 2014, Short-Term Interactive Effects of Biochar, Green Manure, and Inorganic Fertilizer on Soil Properties and Agronomic Characteristics of Maize. Agricultural Research, 3(2), 128-136.

Sanchis, E., Ferrer, M., Torres, A. G., Cambra-López, M., Calvet, S., 2012, Effect of water and straw management practices on methane emissions from rice fields: a review through a meta-analysis. Environmental engineering science, 29(12), 1053-1062.

Sander, B. O., Wassmann, R., Siopongco, J. D. L. C., 2015, Mitigating greenhouse gas emissions from rice production through water-saving techniques: potential, adoption and empirical evidence. In: Climate Change and Agricultural Water Management in Developing Countries, edited by C. T. Hoanh, R. Johnston, V. Smakhtin. CABI Climate Change Series, Vol. 8 (Wallingford, United Kingdon: CABI), pp. 193-207.

Sang, D. A., Bakar, R. A., Ahmad, S. H., Rahim, K. A., 2019, Infuences of rice husk biochar (RHB) on rice growth performance and fertilizer nitrogen recovery up to maximum tillering stage. Journal of Wetlands Environmental Management, 6(1), 32-44.

Sarwar, G., Schmeisky, H., Hussain, N., Muhammad, S., Ibrahim, M., Safdar, E., 2008, Improvement of soil physical and chemical properties with compost application in rice-wheat cropping system. Pakistan Journal of Botany, 40(1), 275-282.

Seetanun, W., De Datta, S. K., 1973, Grain yield, milling quality, and seed viability of rice as influenced by time of nitrogen application and time of harvest. Agronomy Journal, 65(3), 390-394.

Shukla, N., Awasthi, R. P., Rawat, L., Kumar, J., 2012, Biochemical and physiological responses of rice (Oryza sativa L.) as influenced by Trichoderma harzianum under drought stress. Plant Physiology and Biochemistry, $54,78-88$.

Sibayan, E. B., Samoy-Pascual, K., Grospe, F. S., Casil, M. E. D., Tokida, T., Padre, A. T., Minamikawa, K., 2018, Effects of alternate wetting and drying technique on greenhouse gas emissions from irrigated rice paddy in Central Luzon, Philippines. Soil science and plant nutrition, 64(1), 39-46 
Steiner, C., Glaser, B., Geraldes Teixeira, W., Lehmann, J., Blum, W. E., Zech, W., 2008, Nitrogen retention and plant uptake on a highly weathered central Amazonian Ferralsol amended with compost and charcoal. Journal of Plant Nutrition and Soil Science, 171(6), 893-899.

Tran, D. H., Hoang, T. N., Tokida, T., Tirol-Padre, A., Minamikawa, K., 2018, Impacts of alternate wetting and drying on greenhouse gas emission from paddy field in Central Vietnam. Soil science and plant nutrition, 64(1), 14-22.

Wang, C., Liu, J., Shen, J., Chen, D., Li, Y., Jiang, B., Wu, J., 2018, Effects of biochar amendment on net greenhouse gas emissions and soil fertility in a double rice cropping system: A 4-year field experiment. Agriculture, Ecosystems \& Environment, 262, 83-96.

Xie, Z., Xu, Y., Liu, G., Liu, Q., Zhu, J., Tu, C., Amonette, J. E., Cadisch, G., Yong, J. W. H., Hu, S., 2013, Impact of biochar application on nitrogen nutrition of rice, greenhouse-gas emissions and soil organic carbon dynamics in two paddy soils of China. Plant and soil, 370(1-2), 527-540.

Ye, Y., Liang, X., Chen, Y., Liu, J., Gu, J., Guo, R., Li, L., 2013, Alternate wetting and drying irrigation and controlled-release nitrogen fertilizer in late-season rice. Effects on dry matter accumulation, yield, water and nitrogen use. Field Crops Research, 144, 212-224.

Zhang, A., Bian, R., Pan, G., Cui, L., Hussain, Q., Li, L., Zheng, J., Zheng, J., Zhang, X., Han, X., Yu, X., 2012, Effects of biochar amendment on soil quality, crop yield and greenhouse gas emission in a Chinese rice paddy: a field study of 2 consecutive rice growing cycles. Field Crops Research, 127, 153-160.

Zhang, A., Cui, L., Pan, G., Li, L., Hussain, Q., Zhang, X., Zheng, J., Crowley, D., 2010, Effect of biochar amendment on yield and methane and nitrous oxide emissions from a rice paddy from Tai Lake plain, China. Agriculture, ecosystems \& environment, 139(4), 469-475.

Zhang, H., Xue, Y., Wang, Z., Yang, J., Zhang, J., 2009, An alternate wetting and moderate soil drying regime improves root and shoot growth in rice. Crop Science, 49(6), 2246-2260. 